\title{
REFERENCES
}

MCConnell, R. B., 1955. The Erosion Surfaces of Uganda. Colonial Geology and Mineral Resources, 5, 4, 425-8.

Pallister, J. W., 1956. Slope Form and Erosion Surfaces in Uganda. Geol. Mag., xciii, 465-472.

R. B. MCCONNELl.

\author{
Geological Survey Department, \\ LOBATSI, \\ Bechuanaland.
}

11th January, 1957.

\section{FLOW-MARKINGS AND LODE-CASTS}

SIR,--In a recent paper by one of us in this Magazine it was claimed that confusion has arisen around the terms "flow-marking" and "load-cast", and it was proposed to revive the term "flow cast" of Shrock for some structures which might have been described as "load casts". These remarks have led to correspondence between us, the outcome of which is a compromise which may prove of interest to your readers.

We agree that the sole markings of greywacke and sandstone beds may be due to a variety of causes, and as these may operate in combination a certain ambiguity of nomenclature is inevitable. In the course of deposition of a bed of sand on a plastic mud surface, at least five processes may occur; these are:-

(a) Grooving leading to groove casts, long straight furrows filled by the sand.

(b) The cutting of lobate incisions into the mud surface, which incisions are subsequently filled by sand. This process is fluting, and the resulting cast structures are flute casts. We agree with Crowell that this latter term is preferable to "flow markings" which might comprise other structures than those for which Rich introduced it. Flute casts will thus truncate the laminae below them, and within them the laminae will be undisturbed, either horizontal or current-bedded.

(c) The horizontal movement of the base of a bed of sand during or after its emplacement on a mobile substratum, combined with sinking and ploughing up of the latter. This might be called flow, and the resulting structures flow casts. It is not certain that Shrock envisaged this process in coining the term; though he does cite Earp and Sorby who did invoke sediment flow, and his figures 117 and $118 \mathrm{c}$ represent structures which appear to have slid into position. It is clear that in these structures the laminae below and above the cast surface will be equally involved and that the structures must be pulled over in the direction of flow.

As turbidity currents build up their deposits gradually they do not normally give rise to a viscous deposit flowing over and covering a sea floor. Hence, flow casts are rare and restricted to localities where post-depositional movement ensued. But some current drag occurs within a sandy bed as it is formed by a turbidity current. This does not usually leave a visible record, except when superimposed on other sole markings which then become asymmetrical in the current direction. This may be the origin of the asymmetry in the small features Walton (1956) has called "flame structures".

(d) The vertical adjustment of the basal material to unequal loading. The relief of the lower surface causes it to sink into the underlying mud which is of lower density. Part of the structures described by Shrock as flow casts belong in this class. 
The most suitable name for these structures is "load cast"; deformation may affect both beds but is essentially in the vertical sense only; no slumping can be deduced from them, and current drag is insignificant.

(e) Differential compaction, at stages later in the history of the rock, may produce a bending of the laminae below a cast structure. The load cast may thus be deformed as Dzulynski and Radomski (1955, Fig. 6) pointed out. A flute cast may in this way come to resemble a load cast by the deformation of the underlying laminae. It was in this sense that Prentice interpreted the figures given by Carozzi, ${ }^{1}$ in which the undisturbed lamination above the cast suggests a flute cast rather than a load cast. Kuenen claims that such structures might arise by loading, of insignificant irregularities of the mud flow, and he therefore agrees with Carozzi.

A combination of flowing and loading has been invoked by Macar and Antun (1950) to explain their " pseudo-nodules". It is clear that both fluting and flowing will commonly be associated with loading, so that a precise terminology for every structure will probably never be possible.

Many of these structures are not confined to greywacke sequences. Thus, the structures described by Emery (1950) as due to the slow deposition of sand on marshland clay may be compared with load casts. Dunes enroaching on mobile deposits can act in the samie manner. Kryoturbation, in which the mobile condition is induced long after deposition by permafrost and thaw, can also lead to deformation of a load cast type; flow casts may also develop under these conditions as a result of solifluxion.

It is hoped that the terminology here suggested will prove satisfactory. Both authors are actively investigating these and related phenomena, and would welcome any comments from your readers.

\section{REFERENCES}

DzulYNSKI, ST., and A. RAdOMSKI, 1955. Origin of groove casts in the light of turbidity currents hypothesis. Acta Geol. Polonica, v, 1955, 47-66.

Emery, K. O., 1950. Contorted Pleistocene strata at Newport Beach, California. Journ. Sed. Petr., xx, 111-15.

Kuenen, PH. H., 1953. Significant features of graded bedding. Bull. Amer. Ass. Petr. Geol., xxxvii, 1044-1066.

MACar, P., and P. ANTUN, 1950. Pseudo-nodules et glissement sousaquatique dans l'Emsien inférieur de l'Oesling. Ann. Soc. Géol. Belg., lxxiii, B 121-150.

PREnTICE, J. E., 1956. The interpretation of flow-markings and load-casts. Geol. Mag., xciii, 393-400.

SHrock, R. R., 1948. Sequence in layered rocks. New York.

WALtoN, E. K., 1956. Limitations of graded bedding: and alternative criteria of upward sequence in the rocks of the Southern Uplands. Trans. Edin. Geol. Soc., xvi, part iii, 262-271.

Ph. H. Kuenen.

Geological Instirute, MelKWeg 1, Groningen, HOLLAND.
J. E. Prentice.

UNIVERSITY OF LONDON, KiNG'S COLLEGE, STRAND, W.C. 2.

24th January, 1957.

1 The wrong paper was quoted in the list of references. It should be Carozzi, A., 1955. Nouvelles observations microscopiques sur les dépôts de courants de turbidité du Malm de la nappe de Morcles en Haute-Savoie. Bull. Inst. Nat. Genevois, 57, 1-31. 